\title{
PEMBERDAYAAN MASYARAKAT MELALUI KARANG TARUNA MEDAL JAYA DI DESA CIJEMIT KECAMATAN CINIRU KABUPATEN KUNINGAN
}

\author{
Istiqomah $^{1}$ \\ Istiqomah_0409@yahoo.co.id
}

\begin{abstract}
ABSTRAK
Kemiskinan merupakan masalah sosial yang masih relevan untuk dapat dikaji hingga saat ini dan dicarikan solusinya. Dalam penanggulangan kemiskinan perlu juga diperhatikan pendekatan yang memanfaatkan modal sosial yang ada di masyarakat dalam hal ini masyarakat pedesaan yang notabenya memiliki tingkat kemiskinan lebih besar dari pada perkotaan. Salah satunya adalah dengan memanfaatkan peran serta kaum muda di desa. Kaum muda biasanya bergabung dengan kegiatan social salah satunya karang taruna. Terdapat karang taruna yang melakukan pemberdayaan masyarakat yaitu karang taruna Medal Jaya. Karang taruna tersebut memiliki beberapa program pemberdayaan masyarakat. Dari program tersebut semua kegiatannya merupakan pemberdayaan masyarakat karena dalam setiap kegiatan melibatkan masyarakat dan kegiatan tersebut dirancang atas kebutuhan dan kemauan masyarakat itu sendiri. Sehingga dengan adanya kegiatan pemberdayaan masyarakat tersebut karang taruna tersebut mampu mencapai tujuannya diantaranya meningkatkan kesejahteraan masyarakat dan membuka lapangan pekerjaan bagi masyarakat dan masyarakat menjadi lebih mandiri.
\end{abstract}

Kata Kunci: Pemberdayaan masyarakat, modal sosial, karang taruna Medal jaya

\begin{abstract}
Poverty is a social problem that is still relevant to be studied so far and a solution is sought. In poverty alleviation, it is also necessary to pay attention to approaches that utilize social capital in the community, in this case rural communities, which in fact have a greater level of poverty than urban areas. One of them is by utilizing the participation of young people in the village. Young people usually join social activities, one of which is Karang Taruna. There is a youth organization that conducts community empowerment, namely the Jaya Medal Youth Organization. The youth organization has several community empowerment programs. From the program all activities are community empowerment because in every activity involving the community and the activity is designed for the needs and will of the community itself. So that with the
\end{abstract} Kuningan.

${ }^{1}$ Pekerja Sosial Dinas Sosial Pemberdayaan Perempuan dan Perlindungan Anak Kabupaten 
existence of community empowerment activities, the youth organization is able to achieve its objectives including improving the welfare of the community and opening jobs for the community and society to become more independent.

Keyword: Community empowerment, social capital, Youth Medal Jaya

\section{A.Pendahuluan}

Masalah kemiskinan di Indonesia merupakan masalah sosial yang masih relevan untuk dapat dikaji hingga saat ini dan dicarikan solusinya. Ini bukan hanya disebabkan masalah kemiskinan telah ada sejak zaman dahulu, akan tetapi juga karena gejala kemiskinan sulit untuk ditanggulangi. Badan Pusat Statistik (BPS) menunjukkan bahwa jumlah penduduk miskin (penduduk dengan pengeluaran per kapita per bulan di bawah garis kemiskinan) di Indonesia mencapai 26,58 juta orang (8,12 persen), berkurang sebesar 1,19 juta 13orang dibandingkan dengan kondisi Maret 2017 yang sebesar 27,77 juta orang (8,64 persen)Ada pun persentase penduduk miskin di daerah perkotaan sebesar 7,72 persen pada Maret 2017 turun menjadi 7,26 persen pada September 2017. Sementara persentase penduduk miskin di daerah pe-desaan pada Maret 2017 sebesar 13,93 persen turun menjadi 13,47 persen pada September $2017 .^{2}$ Meskipun terjadi

2 Mulyadi, Mohammad, Info Singkat, Vol. X, No. 09/I/Puslit/Mei/2018, hlm. 13. penurunan, tetapi angka tersebut masih ada dan perlu dicarikan solusinya. Dilihat dari dinamika tingkat kemiskinan 2009-2017, kemiskinan di perdesaan lebih tinggi daripada di perkotaan. Berbagai upaya penanganan kemiskinan, diperlukan pula upaya terobosan untuk mengatasi persoalan kesenjangan sosial ekonomi. Adapun penyebab terjadinya antara lain adanya kesempatan yang belum merata, akses terhadap lapangan pekerjaan yang belum merata dan kepemilikan aset masih terkonsentrasi pada kelompok masyarakat yang kaya. Selama ini, masih terjadi ketidakadilan dalam pembangunan di bidang infrastruktur, baik jalan, irigasi, maupun kelistrikan yang masih berkutat di wilayah Jawa sebesar 58,4 persen dan Sumatera 22 persen. Konsentrasi ekonomi di Jawa dan Sumatera ini merupakan akibat dari konsentrasi wilayah industri.

Kaum muda merupakan aset bangsa yang sangat mahal dan tidak ternilai harganya. Kaum muda mempunyai peran dan fungsi yang sangat strategis dalam pembangunan 
bangsa dan negara. Jika peranan tersebut dijalankan dengan penuh komitmen, didasari dengan nilainilai agama dan ilmu pengetahuan maka kaum muda dapat meningkatkan kesejahteraan rakyat.

Kaum muda dapat memberikan energi, gagasan kreatif dan tekad untuk mendorong reformasi. Menurut Sekretaris Jenderal (Sekjen) PBB me-ngatakan bahwa kaum muda sering menjadi yang pertama berdiri melawan ketidakadilan, masa muda merupakan masa-masa idealisme dan dapat menjadi kekuatan untuk transformasi. ${ }^{3}$ Potensi yang dimilik kaum muda, kaum muda menjadi agent of change (agen perubahan) sebagai pengakuan eksistensinya, biasanya kaum muda bergabung dalam kegiatan-kegiatan sosial untuk menjadi relawan karena mempunyai semangat dan rasa kepedulian yang tinggi.

Relawan adalah seseorang atau kelompok orang yang secara ikhlas karena panggilan nuraninya memberikan apa yang dimilikinya (pikiran, tenaga, waktu, dan sebagainya) kepada masyarakat sebagai perwujudan tang-gungjawab sosialnya tanpa meng-harapkan pamrih baik berupa imbalan (upah),

${ }^{3} \mathrm{UN}$ _Youth_Volunteers_Programme.pdf dalamhttps://www.unv.org/sites/default/files/U N_Youth_Volunteers_Programme.pdf, diakses pada Rabu, 05Juli 2017 pukul 04. 30 WIB. kedudukan, kekuasaan, kepentingan maupun karier. ${ }^{4}$ Relawan biasanya bergerak secara independen atau melalui lembaga-lemabaga sosial kemasyarakatan. Namun ada kerelawanan di bawah naungan pemerintahan salah satunya adalah relawan pada karang taruna yang menyasar kaum pemuda. Karang taruna adalah organisasi sosial kemasyarakatan sebagai wadah dan sarana pengembangan setiap anggota masyarakat yang tumbuh dan berkembang atas dasar kesadaran dan tanggungjawab sosial dari, oleh dan untuk masyarakat terutama generasi muda di wilayah desa/kelurahan terutama bergerak di bidang usaha kesejahteraan sosial. ${ }^{5}$

Karang Taruna merupakan organisasi masyarakat di bawah naungan pemerintahan yang ada di setiap desa atau kelurahan, kiprahnya sebagai karang taruna sangat mempengaruhi kesejahteraan masyarakat. Jumlah Karang Taruna di seluruh Indonesia mencapai 62 ribu lebih. Idealnya setiap desa di Indonesia yang jumlahnya lebih dari

${ }^{4}$ Booklet Relawan dalamwww.p2kp.org/pustaka/.../relawan/4_ISI_ BOOKLET_Relawan.doc,diakses pada Kamis, 06 Juli 2017.

${ }^{5}$ Peraturan Menteri Sosial Republik Indonesia Nomor: 77/ HUK/ 208 tentang Pedoman

Dasar Karang Taruna. 
80 ribu, memiliki sekurangnya satu unit Karang Taruna. ${ }^{6}$

Sebelumnya pada tahun 2015 terdapat Karang Taruna yang aktif untuk membantu masyarakat dan membantu kehidupan yang lebih baik dalam segi sosial, ekonomi, pendidikan, budaya dan kultur, agama, dan kesehatan. Karang Taruna yang aktif tergantung dari para warganya yang dalam hal ini adalah relawan. Ada salah satu karang taruna yang berhasil mampu melakukan pemberdayaan masyarakat untuk kesejahteraan dan dapat meraih prestasi membanggakan bagi Kabupaten Kuningan, karena dalam kesempatannya meraih juara 1 tingkat Nasional kategori karang taruna berkembang tahun 2015 yaitu Karang Taruna Medal Jaya di Desa Cijemit Ciniru Kabupaten Kuningan Jawa Barat.

Dari latar belakang di atas, dapat dirumuskan bahwa kemiskinan tertinggi justru terjadi di pedesaan dan terdapat salah satu desa di Kuningan yang mempunyai institusi sosial kepemudaan dalam hal ini karang taruna yang cukup konsen dalam memecahkan permasalahan kemiskinan melalui kegiatan pemberdayaan masyarakat. Maka dari itu penelitian ini merumuskan permasalahan: Bagaimana Pemberdayaan Mayarakat yang dilakukan oleh Karang Taruna Medal Jaya di Desa Cijemit Kecamatan Ciniru Kabupaten Kuningan?

\section{B. METODE PENELITIAN}

Untuk menggambarkan kegiatan pemberdayaan masyarakat yang dilakukan oleh karang taruna medal jaya di Desa Cijemit, peneliti menggunakan pendekatan kualitatif, melalui pengumpulan data kepada enam orang anggota karang taruna Medal Jaya di Desa Cijemit. Anggota Karang Taruna yang diwawancarai dilakukan secara snowballing. Metode pengumpulan data yang digunakan adalah wawancara (interview), pengamatan (observation), dan studi dokumentasi. $^{7}$

Jenis wawancara penelitian ini adalah wawancara terpimpin yaitu wawancara yang menggunakan panduan pokok-pokok masalah yang diteliti. Adapun data yang digali melalui teknik ini adalah kegiatan pemberdayaan masyarakat yang dilakukan oleh karang taruna Medal

7 Juliansyah Noor, Metodologi Penelitian, (Jakarta: Kencana Perdana Media group,2011), hlm.138.s 
Jaya di Desa Cijemit Kecamatan Ciniru Kabupaten Kuningan.

Sedangkan teknik observasi yang digunakan dalam penelitian ini adalah mengamati secara langsung dengan teliti. Beberapa informasi yang diperoleh dari hasil observasi antara lain: ruang (tempat), pelaku, kegiatan, objek, perbuatan, kejadian atau peristiwa, waktu, dan perasaan. Selain itu, dalam teknik dokumentasi digunakan karena sebagian besar data dan fakta tersimpan dalam bentuk dokumentasi.

\section{KERANGKA TEORI}

\section{Konsep Pemberdayaan Masyarakat}

\section{a. Pengertian Pemberdayaan masyarakat}

Menurut Zubaedi pemberdayaan masyarakat adalah suatu cara yang memungkinkan setiap orang dapat meningkatkan kualitas hidupnya serta mampu memperbesar pengaruhnya terhadap proses-proses yang mempengaruhi kehidupannya. ${ }^{8}$

Sukriyanto mengatakan bahwa pemberdayaan masyarakat adalah upaya setiap

${ }^{8}$ Zubaedi, Pengembangan Masyarakat Wacana dan Praktik, (Jakarta: Kencana Prenada Media Group, 2013), hlm. 4. individu-individu dalam meningkatkan kesejahteraan masyarakat dengan meningkatkan pendapatan ${ }^{9}$. Selain itu menurut Kartasasmita pemberdayaan masyarakat adalah pembangunan yang bertumpu pada pertumbuhan yang dihasilkan oleh upaya pemerataan, dengan penekanan pada peningkatan kualitas sumber daya manusia. ${ }^{10}$ Dengan demikian pemberdayaan masyarakat dapat disimpulkan sebagai metode setiap individu dalam melakukan kegiatan masyarakat yang menekankan pada sumber daya manusia untuk mencapai kesejahteraan sosial dan memperbaiki kualitas kehidupan masyarakat itu sendiri.

\section{b. Tujuan Pemberdayaan}

\section{Masyarakat}

Menurut Muslim dalam buku Islam Dakwah dan Kesejahteraan Sosial mengatakan bahwa tujuan pemberdayaan masyarakat adalah pemberdayaan

\footnotetext{
${ }^{9}$ Sukriyanto, "Pengembangan Masyarakat Islam Agama, Sosial, Ekonomi dan Budaya", Populis Jurnal Pengembangan Masyarakat, Edisi No. III / 2003 (Yogyakarta: UIN Sunan Kalijaga, 2003), hlm. 31.

${ }^{10}$ Ginanjar Kartasasmita, Pembangunan untuk Rakyat Memadukan Pertumbuhan dan Pemerataan, (Jakarta: Cides, 1996), hlm. 142.
} 
(empowerment) masyarakat dan meningkatkan kesejahteraan masyarakat serta kualitas hidup manusia atau peningkatan harkat martabat manusia. ${ }^{11}$ Pemberdayaan berarti mengembangkan kekuatan atau kemampuan (daya), potensi, sumber daya manusia agar mampu membela dirinya sendiri. ${ }^{12}$ Selain itu Cholisin mengatakan bahwa tujuan dari pengembangan ekonomi masyarakat adalah memampukan dan memandirikan masyarakat terutama dari kemiskinan dan keterbelakangan/kesenjangan dan ketidakberdayaan. $^{13}$
${ }^{11}$ Azis Muslim,"Paradigma Pengembangan Masyarakat", dalam Suisyanto, Islam Dakwah dan Kesejahteraan Sosial, (Yogyakarta: Jurusan PMI Fakultas Dakwah Uin Sunan Kalijaga bekerja sama dengan IISEP-CIDA), hlm. 5.

${ }^{12}$ Azis Muslim, "Konsep Dasar Pengembangan Masyarakat”, Populis Jurnal Pengembangan Masyarakat, vol. 5:1 (Januari, 2007), hlm. 21-22.

${ }^{13}$ Cholisin, disampaikan pada Gladi Manajemen Pemerintahan Desa bagi Kepala Bagian/ Kepala urusan Hasil Pengisian Tahun 2011 di Lingkungan Kabupaten Sleman. http://staff.uny.ac.id/sites/default/files/tmp/PEM BERDAYAAN\%20MASYARAKAT.pdfDi akses pada Jum'at 14 Maret 2014.
D.KARANG TARUNA MEDAL JAYA: MODAL SOSIAL DALAM PEMBERDAYAAN MASYARAKAT

Karang Taruna Medal Jaya Desa Cijemit merupakan karang taruna yang melakukan pemberdayaan masyarakat. Kiprahnya sangat berpengaruh ter-hadap masyarakat. Dengan beberapa kegiatan yang dilakukan karang taruna medal jaya menarik perhatian beberapa pihak termasuk pemerintahan desa, kecamatan, kabupaten, provinsi bahkan nasional. Dengan keberhasilannya dapat meraih juara 1 Karang Taruna Medal Jaya se-Indonesia. Prestasinya pun tidak diragukan lagi, karena selain kegiatan yang dilakukannya, warga masyarakat Desa Cijemit begitu guyub dan rukun, sehingga kompak dan selalu bekerjasama dalam berbagai kegiatan yang di pelopori oleh anggota Karang Taruna Medal Jaya. Ada pun beberapa kegiatan yang dilakukan oleh karang taruna medal jaya di antarannya:

1. Bidang Pendidikan dan Kerohanian

Bidang ini dibagi lagi menjadi dua bagian yaitu bidang pendidikan dan bidang kerohanian untuk 
penjelasan dari setiap programnya sebagai berikut. ${ }^{14}$

a. Pendidikan

Pada bidang ini terdapat 8 program pendidikan dan 8 program kerohanian, program yang pertama pengadaan taman bacaan/Rumah Belajar Khusus PMKS, program untuk PMKS ini masuk ke majlis ta'lim kegiatannya adalah belajar baca Al-Qur'an setiap hari Jum'at sore dengan prinsip bisa atau tidak bica baca Al-Qur'an harus tetap hadir dan membawa AlQur'an, tempatnya di Masjid karena tidak ada rumah yang kosong.

Program yang kedua dari bidang pendidikan ini adalah pendataan dan penanggulangan anak rentan putus sekolah. Dalam program kedua ini bidang pendidikan dan kerohanian bekerjasama dengan bidang pelayanan kesejahteraan sosial bersama-sama mendata anak yang rentan maupun putus sekolah. Sementara untuk penanggulangannya ada yang dinamakan rumah belajar anak bintang (RaJAB) yaitu pendidikan nonformal setelah

14 Wawancara dengan Bapak AY, Bidang Pendidikan dan Kerohanian, pada tanggal 21 Agustus 2017 pulang sekolah. Tapi kegiatan tersebut tergantung anaknya walaupun sudah di-motivasi dari keluarganya, se-kolahnya, karang taruna dan lingkungannya, semua keputusan di-kembalikan kepada anak. Kegiatan RaJAB ini adalah membahas tentang nilai-nilai yang berkaitan dengan moral dan memberikan pendidikan karakter terhadap anak. ${ }^{15}$

Program yang ketiga dari bidang pendidikan adalah pendataan dan penanggulangan warga yang buta aksara. Program ini bekerjasama dengan bidan pelayanan kesejahteraan sosial, setelah pendataan ternyata tidak ada warga yang buta aksara, tapi program ini tetap ada dikhawatirkan ke depannya ada yang buta aksara tetapi terlewat dalam pendataan.

Program yang keempat yaitu mengadakan lomba-lomba bidang pendidikan (Cerdas Cermat, Menggambar, dll) program ini biasanya dilakukan mulai dari tingkat dusun, kecamatan sampai ke kabupaten. Juara kecamatan sudah tiga kali berturut-turut di-

15 Wawancara dengan TH, Majlis Permusyawaratan Karang Taruna (MPKT) sekaligus pengurus Rumah Belajar Anak Bintang (RaJAB), pada tanggal 15 Juli 2017. 
menangkan oleh desa Cijemit sebagai juara umum. Sebelumnya anak-anak belajar di tempat belajar kegiatan karang taruna (pondok pesantren AlHuda) baik pelajaran umum maupun keagamaan. Kegiatan lomba Cerdas Cermat tingkat dusun dibiayai oleh Paguyuban Keluarga Besar Cijemit (PKBC).

Program kelima yaitu membuka kursus-kursus/keterampilan (menjahit, menganyam, memasak, dll). Program ini kerja sama antara karang taruna, desa dan dinas sosial pemberdayaan perempuan dan perlindungan anak tentang pelatihan menjahit untuk ibu-ibu dan beberapa pelatihan usaha lainnya. Selain pelatihan menjahit, ada juga pelatihan patukangan untuk bapak-bapak.

Program keenam yaitu membuka perpustakaan mini, program ini sudah ada yang bertempat di sekretariat karang taruna. Selain itu, di Tempat mengaji (pondok pesantren AlHuda) terdapat buku-buku anak dalam lemari untuk bacaan anak-anak. buku yang ada di lemari tersebut masih minim karena hanya pemberian dari orang-orang yang bekerja di
Jakarta belum mengajukan buku ke Instansi-Instansi.

Program ketujuh yaitu pembuatan Tabloid Karang Taruna, dalam Hal ini pembuatan tabloid seperti majalah atau buku belum ada. program pembuatan tabloid ini baru rencana untuk ke depannya. Karang taruna baru membuat kalender dan brosur-brosur terkait karang taruna.

Selanjutnya program kedelapan adalah ikut serta dalam kegiatan peringatan hari besar nasional, salah satu contohnya adalah bulan Ramadhan adanya beberapa perlombaan di antaranya MTQ, hafidz, hapalan yasin full, hafalan alWaqiah, hafalan juz amma, dan shalawat marawis. Sebelum diadakan perlombaan pada bulan Ramadhan adanya bimbingan belajar dari bidang kerohanian. Pendanaan yang digunakan adalah dana dari PKBC, karang taruna hanya memotivasi dan memfasilitasi tempat kegiatan. Biasanya tempatnya di Masjid dan untuk lomba Pildacil di Balai desa.

Program kesembilan adalah melaksanakan pendidikan dan pelatihan kebangsaan, program ini masih rencana untuk ke depannya. 
Tapi dasar-dasar sudah dikembangkan di sekolah.

Program kesepuluh adalah mengembangkan pendidikan kepanduan atau kepramukaan, desa Cijemit sudah memiliki Pramuka Desa (Pramdes) yang digagas oleh Karang Taruna. Kegiatannya mengikuti kegiatan pramuka pada umumnya. Ketika ada Camping Pramdes Cijemit mengikutinya, terkadang melakukan Camping sendiri untuk warga Karang Taruna Medal Jaya. Beberapa pengurus Karang Taruna juga aktif di Provinsi seperti DN dan YS yang biasanya ikut mewakili Jambore.

b. Kerohanian

Pada bidang ini terdapat 8 program kerohanian yang dilakukan oleh Karang Taruna Medal Jaya. Program yang pertama adalah mengadakan pengajian dan bedah Qur'an khusus warga Karang Taruna. Program ini seperti membaca 1 ayat dalam Al-Qur'an kemudian dibahas dan dikaji isi kandungan ayat tersebut bersamasama dengan bapak-bapak dan ibu-ibu warga Karang Taruna. Jadwalnya untuk bapak-bapak setia malam ahad (minggu) dan untuk ibu-ibu setiap hari Jum'at sore.
Program yang kedua adalah mengadakan dan mengikuti lomba-lomba bidang keagamaan seperti mengadakan dan mengikuti kegiatan bulan Ramadhan.

Selanjutnya program yang ketiga adalah melaksanakan/ikut serta dalam kegiatan Peringatan Hari Besar Agama Islam. Seperti acara maulud dan tahun baru Islam biasanya malamnya suka diadakan pawai obor dengan peserta seluruh masyarakat kurang lebih 500 keliling ke pasar Ciniru dan paginya diadakan lomba-lomba rias sepeda antar dusun.

Program keempat adalah megadakan pendidikan mental melalui pembinaan kerohanian seperti kegiatan pengajian setiap malam Jum'at untuk pengurus Karang Taruna. kegiatan ini biasanya dimulai dengan membaca Al-Qur'an terlebih dahulu kemudian sharing dengan membahas satu kata misalkan tentang sabar. Maka sabar tersebut menjadi tema pengajian.

Program yang kelima adalah turut serta dalam rangka pelaksanaan ta'ziah/pemulangan jenazah artinya warga karang taruna ikut serta dalam pemulangan jenazah sampai ke makam. Tapi dalam hal ini tidak 
semua warga karang taruna karena biasanya ada kesibukan masing-masing, jadi ketika ada warga yang benar-benar sibuk, warga hanya melakukan takziah. Tetapi, khusus koordinator kerohanian mengikuti proses dari ngerumat sampai pemakaman.

Program keenam adalah Pembentukan Ikatan Remaja Masjid. Program ini baru dilaksanakan tahun ini yaitu dengan membentuk remaja masjid karena antusias remaja di desa Cijemit.

Program ketujuh adalah turut serta dalam pengembangan pondok pesantren, salah satu pengembangan pondok pesantrennya adalah pembentukan Ikatan Remaja Masjid.

Program yang kedelapan adalah mengadakan pembelajaran IQRA bagi lansia, program ini diserahkan ke setiap dusun dengan metodenya masing-masing. Kalau dulu, pembelajaran Iqra untuk lansia ini keliling ke setiap mushola masih ada. tapi sekarang sudah tidak ada, malah sudah bisamemcaba Al-Qur'an.

2. Bidang Pelayanan Kesejahteraan Sosial

Pada program ini merupakan program prioritas dalam pelayanan kesejahteraan sosial masyarakat program tersebut adalah: ${ }^{16}$

Melakukan pendataan dan penanggulangan warga PMKS. Pengurus karang taruna melakukan pendataan PMKS dengan 26 jenis PMKS setiap tahunnya diantaranya terdapat anak terlantar sebanyak 32 orang, anak dengan kedisabilitasan 1 orang, lanjut usia sebanyak 47 orang, penyandang disabilitas sebanyak 7 orang, perempuan rawan sosial ekonomi sebanyak 36 orang, pakir miskin 49 orang dengan total keseluruhan 152 orang. PMKS yang didata diberikan sumbangan uang atau pakaian setiap tahun yang bersumber dari kas karang taruna, kenclengan ${ }^{17}$ dan dari PKBC dan HPPC.

Membantu dan memfasilitasi warga dalam proses pengajuan dan pelaksanaan rumah tidaklayak huni (RUTILAHU). Setiap tahunnya karang taruna membantu dalam RUTILAHU baik tenaga maupun materi, bantuan tenaga biasanya di-jadwal perhari misalkan 3 orang peng-urus karang taruna. Sudah sekitar 7 rumah yang dibantu dengan sumbangan uang ada yang Rp. 3.000.000,00 ada

16 Wawancara dengan AN, Bidang Pelayanan Kesejahteraan Sosial Karang Taruna MedalJaya, pada tanggal 19 Juli 2017.

17 Pengumpulan uang receh (koin) dari setiap rumah (wawancara dengan $\mathrm{AN}$, pada tanggal 19 Juli 2017) 
yang Rp. 4.000.000,00 tergantung rumahnya yang di bangun. Desa pun sama-sama memberikan sumbangan keuangan untuk RUTILAHU. Keuangnan untuk RUTILAHU dari kenclengan, kas karang taruna, PKBC dan HPPC. Pembagian pendapatan keungan karang taruna adalah santunan PMKS 30\%, RUTILAHU 30\%, dan kas karang taruna $40 \%$.

Turut serta dalam tanggap bencana, karang taruna ikut serta dalam tanggap bencana biasanya bersamaan dengan melakukan Kemah Bhakti pada daerah bencana. Melakukan kunjungan ke warga yang sakit dan dirawat di Rumah Sakit, gotong royong warga karang taruna desa Cijemit masih memiliki kerjasama dan saling menolong yang erat.

Melakukan

kerjasama

dengan dinas terkait kesejahteraan sosial, salah satunya dengan dinas sosial Kabupaten Kuningan, terkait pengajuan Jamkesda atau pun BPJS gratis bagi warga yag kurang mampu. Ataupun dalam hal lainnya seperti pelatihan dan sosialisasi kesejahteraan sosial.

Turut serta dalam penanggulangan dan pemanfaatan sampah rumah tangga, warga karang taruna mempunyai program pengelolaan bank sampah di mana setiap rumah disediakan tempat sampah baik organik, anorganik dan kaca/keramik. Kemudian sampah tersebut dikumpulkan dari setiap rumah dan dijual dengan bekerjasama dengan Badan Lingkungan Hidup (BLH) Kuningan. ${ }^{18}$

Kemudian, turut serta dalam kebersihan lingkungan, setiap hari Jum'at, warga melakukan jum'at bersih (jumsih) yaitu kegiatan membersihkan lingkungan sekitar.

3. Bidang Rekreatif, Olahraga dan Kesenian (ROK)

Pada bidang ROK ini dibagi lagi menjadi 3 bagian yaitu bidang rekreatif terdiri dari enam program, bidang olahraga terdiri dari tujuh program, dan bidang kesenian terdiri dari delapan program. Di bawah ini adalah uraian dari setiap program. ${ }^{19}$

a. Bidang Rekreatif

Program yang pertama adalah membuka lahan untuk dijadikan obyek wisata. Karang Taruna Medal Jaya memiliki tanah yang dinamakan Godol yaitu tanah yang diberikan desa untuk dijadikan tempat wisata oleh karang taruna. Warga karang taruna membuat lintasan untuk dijadikan ofroad sebagai

${ }^{18}$ Observasi rumah WN, pada tanggal 21 Agustus 2017

${ }^{19}$ Wawancara dengan DN, Bidang ROK Karang Taruna MedalJaya, pada tanggal 20 Agustus 2017 
jalan mobil gunung. Orang yang kerja di Godol tersebut adalah warga karang taruna tetapi ada juga dari luar desa karena terkadang warga karang taruna mempunyai kesibukan. Sekali lintasan mobil dibayar Rp. 20.000,00 tetapi selain bayar lintasan juga beberapa pelajar menjadi kenek di tempat yang sulit untuk dilintasi dengan bayaran seikhlasnya.

Program kedua adalah mengadakan Wisata Bhakti dan Gelar Budaya. Kemah bhakti adalah kegiatan kunjungan ke desa-desa yang membutuhkan bantuan seperti butuh tenaga dalam pembuatan irigasi atau desa yang karang tarunanya tidak aktif. Pada saat kemah pengurus karang taruna Medal Jaya mengadakan kegiatan baksos untuk disumbangkan ke masyarakat setempat yang membutuhkannya seperti pakaian-pakaian bekas. dan religi yaitu melakukan kunjungan ke sebuah kerajaan pangeran mangkubumi dan dewi cengkrawati sebagai awal mulanya terbentuk Cijemit. Selain itu, warga karang taruna melalukan ziaroh ke makam abah Kemit (seorang pendiri desa Cijemit) dengan membersihkan makamnya.
Program keempat, mengadakan pameran dan galeri karang Taruna yaitu kegiatan pameran seperti Kemah Bhakti dan penjualan buwu (semacam jarring ikan yang terbuat dari kayu) dan penjualan mainan perahu.

Program kelima, membuka bidang usaha sendiri melalui kreativitas yaitu penjualan buwu ke luar desa, karena banyaknya pesanan dari luas desa makan pengrajin buwu menjadikan kreativitasnya sebagai usaha. Selain buwu, usaha lainnya adalah perbaikan lintar (jaring ikan).

Selanjutnya program keenam, penanaman seribu pohon melalui program konservasi. Kegiatan ini kerjasama antara warga karang taruna dengan tagana.

b. Bidang Olahraga

Dalam program Olahraga ini memiliki beberapa program, tetapi ada program prioritas di antaranya:

Program pertama, mengadakan pembinaan dan pelatihan sepak bola dan volly ball. Jadwal pelatihan Sekolah Sepak Bola (SSB) ini setiap Jum'at dan minggu dengan sasaran yang berbeda mulai usia 
SD, SMP dan SMA. SSB juga mempunyai target sasaran usia 23 untuk mengikuti turnamen Kuningan Cup setiap tahunnya. Selain SSB kegiatan unggulan lainnya adalah volley ball dan badminton.

Program kedua, membentuk tim Sepak Bola "Pesopati" dan tim Volly Ball. Pesopati adalah nama tim sepak bola desa Cijemit yang dibentuk dari perwakilan setiap dusun untuk kegiatan gala desa di Kabupaten. Perekrutan tim sepak bola dan volly dari setiap dusun ini supaya tidak terjadi perpecahan antar dusun.

Program ketiga, mengikuti event atau turnamenturnamen olahraga antar kampong/dusun yaitu mengikuti turnamen antar desa di kabupaten yang di sebut gala desa dan Kuningan cup. Turnamen tingkat desanya seperti turnamen sepak bola dan volly ball antar dusun pada kegiatan Agustusan.

Program keempat, mengembangkan olahraga tradisional seperti yang sudah dipaparkan di atas, olahraga tradisonal ini adalah rorodaan yang sebelumnya olahraga ini dilakukan oleh orang-orang zaman dahulu. Olahraga rorodaan ini dilestarikan oleh Karang Taruna Medal Jaya sebagai budaya.

c. Bidang Kesenian

Program pertama, mengembangkan potensi Paguyuban Seni Daniang Medal Jaya. Dalam program ini pemuda mengembangkan kesenian tradisional Daniang Medal Jaya yaitu semacam kesenian bonang. Sasarannya adalah pemuda putri usia SMP dengan pelatih seorang guru dari SMP Ciniru. Selain itu, pemuda SMP juga dilatih untuk menjadi pagar bagus dan pemegang payung saat acara nikahan.

Program kedua, pengadaan kelengkapan sarana atau alat kesenian tradisional dan modern serta pemanfaatannya. Pada program ini pengurus karang taruna terutama bidang kesenian mendata alat kesenian yang dimiliki seperti calung, gendang, dan keyboard. Sasarannya calung oleh pemuda putra sebagai anggota/warga karang taruna, sedangkan keyboard, dan gendang digunakan oleh pengurus dewasa. Alat-alat kesenian ini juga dimanfaatkan ketika dari desa atau sekolah lain untuk menyewanya. 
Program ketiga, mengadakan pendidikan dan latihan kesenian secara berkesinambungan yaitu adanya pembelajaran dan latihan kesenian secara berkesinambungan seperti latihan calung dan goong setiap malam minggu yang melatih adalah pengurus karang taruna yaitu TH dan KS. Selain itu juga dilatih pembuatan lagulagu yang mengiri goong tersebut.

Program keempat, melakukan pendataan dan pemeliharaan sarana/alat kesenian. Pada program ini pengurus karang taruna melakukan pendataan terhadap alat kesenian milik karang taruna. Misalkan terdapat alat yang rusak dan belum punya, maka melakukan pengajuan ke desa. Tetapi, kebanyakan bantuan diberikan dari sponsor seperti PKBC. Selain itu juga bantuan lain seperti dari Kick and D mendapatkan bantuan bola sebanyak 28 bola.

Program kelima, melestarikan seni tradisional melalui pagelaran seni dan budaya/gelar budaya. pagelaran ini biasanya dilakukan setiap ulang tahun Karang Taruna Medal Jaya pada tanggal 27 Oktober.
Program keenam, melakukan kerjasama internal dan eksternal dalam rangka pengembangan kesenian. Salah satu contoh kerjasama internal yaitu dengan pihak dalam desa seperti ketika adanya hajatan, kesenian dari karang taruna tampil sebagai ajang promosi. Kemudian kerjasama eksternal salah satu contohnya dengan tetangga desa.

Program ketujuh, melestarikan seni tradisional yang merupakan kearipan lokal (doging, dog-dog, dll). Doging adalah kegiatan yang dilakukan ketika ada acara sunatan seperti orang-orangan manusia asli yang memakai topeng badannya diikat dengan injuk, tujuannya adalah untuk menakut-nakuti orang jaman dahulu. Sedangkan dog-dog adalah musik pengiring doging.

4. Bidang Pengembangan UEP dan UKM

Bidang pengembangan Usaha Ekonomi Produktif (UEP) dan Usaha Kecil Menengah (UKM) terdapat lima program. ${ }^{20}$

Program pertama, pendidikan dan pelatihan kewirausahaan. Ada beberapa pelatihan

20 Wawancara dengan WN, Bidang Pengembangan UEP dan UKM Karang Taruna MedalJaya, pada tanggal 21 Agustus 2017. 
kewirausahaan yang dilakukan oleh karang taruna Medal Jaya. Salah satunya adalah pelatihan penanaman jahe sampai proses pembuatan wedang jahe dan pemasarannya. Pelatihan ini kerjasama dengan Dinas Pertanian Kabupaten Kuningan. Ketika pengurus karang taruna sudah bisa mempraktikkan pelatihan tersebut. Maka pengurus karang taruna melakukan pelatihan kepada warga karang.

Program kedua, pengembangan Kube (Kelompok Usaha Bersama) bidang peternakan seperi kambing dan lele. Karang taruna Medal Jaya memiliki peternakan kambing yang masih berjalan. Kambing tersebut dirawat bersamasama oleh pengurus karang taruna dengan jadwal mencari rumput dan memberi makan kambing setiap harinya.

Program ketiga, pengembangan binaan industri perumahan (Home Industri) seperti produksi tempe. Warga karang taruna mempunyai home industri pembuatan tempe sampai saat ini terus berjalan bahkan pemasok tempe ke supermarket dan toko- toko besar di kuningan.

Program keempat, pengembangan bidang UEP, pengurus karang taruna mempunyai Usaha Ekonomi Produktif diantaranya wedang jahe, keripik cimol, rengginang, keripik gadung dan tempe. Dari keempat UEP tersebut yang paling laris adalah wedang jahe dan keripik cimol.

Program kelima, pengembangan binaan usaha kecil menengah. Program ini berkaitan dengan UEP. Produksi UEP tersebut termasuk UKM yang terus dikembangkan.

5. Bidang Pemberdayaan Perempuan

Bidang ini memiliki 6 program di antaranya sebagai berikut: ${ }^{21}$ Program pertama, mengadakan pendidikan dan pelatihan keterampilan khusus perempuan. Pada program ini telah diadakan pelatihan pembuatan wedang jahe, cimol dan keripik gadung. Pelatihan wedang jahe bekerjasama dengan Dinas Pertanian, di mana pertanian memberikan sumbangan bibit jahe untuk ditanam, cara penanaman jahe, sampai pengolahan jahe. Kemudian, hasil pelatihan yang didapatkan oleh ibu-ibu disalurkan lagi kepada pemuda-pemudi karang taruna. Tetapi pelatihan dilakukan secara informal dan fleksibel seperti salah satu contoh ketika ibuibu sedang membuat wedang jahe, cimol dan keripik gadung, ibu-ibu

21 Wawancara dengan JN, Bidang Pemberdayaan Perempuan Karang Taruna MedalJaya, pada tanggal 21 Agustus 2017. 
mengajak pemuda-pemudi dalam proses pembuatannya. Sehingga pemuda-pemudi karang taruna mengetahui cara pembuatannya. Kemudian pelatihan cimol sama seperti pelatihan wedang jahe diajak secara fleksibel, kalau cimol ini lebih ke bidang UEP dan UKM koordinatornya WN. Adapun pelatihan pembuatan keripik gadung sama hal-nya dengan pelatihan di atas. Gadung merupakan salah satu potensi di Desa Cijemit, karena gadung tanpa ditanam tumbuh sendiri di kebun, gadung yang diambil dan diproses adalah gadung yang sudah tua. Prosesnya harus benar-benar yang sudah mengerti karena harus menghilangkan racun yang dikandungnya.

Program kedua, peran serta dalam pelaksanaan POSYANDU yaitu pengurus karang taruna bidang pemberdayaan perempuan ikut serta dalam kegiatan posyandu sekaligus menjadi ketua posyandu. Posyandu di desa Cijemit aktif dan antusias, di sisi lain sudah ada penghargaan kepada pengurus posyandu seperti sekali kegiatan posyandu diberikan uang transport dari Dana Desa.

Program ketiga, pendidikan dan pelatihan kewirausahaan. Program ini sama dengan program yang per-tama dan sama juga dengan bidang UEP dan UKM. Selanjutnya program keempat, mengembangkan Kube, UEP, dan Home Industri lainnya, program ini dilakukan bersama-sama dengan bidang UEP dan UKM. Program kelima, pengembangan binaan industri perumahan (home industri) salah satunya adalah pem-buatan tempe. Program yang keenam, pengembangan binaan usaha kecil menengah, program ini bersamasama dengan bidang UEP dan UKM.

Selain sasaran program Karang taruna Medal Jaya mempunyai target dan tujuan di antaranya adalah: ${ }^{22}$

1. Terciptanya akhlak dan budi pekerti pemuda yang dilandasi dengan keimanan dan ketakwaan.

2. Terciptanya kerukunan dan persatuan di antara pemuda.

3. Mampu menciptakan kesejahteraan bagi masyarakat melalui kegiatan sosial kemasyarakatan (bakti sosial, kesehatan keagamaan, dll).

4. Mampu menciptakan lapangan kerja dan usaha produktif dalam rangka pemberdayaan pemuda

${ }^{22}$ Profil Karang Taruna Medal Jaya Desa Cijemit Kecamatan Ciniru Kabupaten Kuningan Provinsi Jawa Barat, Bersama Membangun Masyarakat, Dokumen, 19 Juli 2017. 
dalam kurun waktu lima tahun kedepan melalui kewirausahaan atau udah lain yang produktif.

5. Menciptakan prestasi dalam bidang olahraga, seni/budaya, dan prestasi dibidang lainnya.

6. Menciptakan pemuda yang handal dan siap pakai dalam menghadapi dunia kerja.

7. Mampu mengurangi angka pengangguran di Desa Cijemit sebesar 25\% dalam kurun waktu lima tahun ke depan.

8. Terciptanya hubungan yang harmonis dan bersinergi antar karang taruna dengan pemerintahan desa sebagai mitra kerja dalam upaya meningkatkan kualitas pembangunan.

Program yang dilakukan oleh karang taruna Medal Jaya Desa Cijemit merupakan kegiatan pemberdayaan masyarakat, kegiatan pemberdayaan masyarakat tersebut diikuti oleh masyarakat mulai dari anak-anak, pemuda-pemudi, orang dewasa sampai lansia. Kegiatan tersebut dilakukan atas dasar partisipasi masyarakat di mana masyarakat mengikuti kegiatan dengan kesadaran sendiri tanpa paksaan. Setiap kegiatannya baik anak-anak hingga lansia disesuaikan dengan kebutuhan masyarakat terlihat dari programnya seperti pendidikan, kerohanian, pelayanan kesejahteraan sosial, olahraga, kesenian, pengembangan usaha ekonomi produktif, dan pemberdayaan perempuan. Hal ini sesuai dengan konsep pemberdayaan masyarakat di atas.

Selain itu target dan tujuan dari kegiatan yang dilakukan oleh karang taruna Medal Jaya sesuai dengan teori di atas tentang tujuan pemberdayaan masyarakat yaitu untuk meningkatkan kesejahteraan masyarakat dan meningkatkan harkat martabat manusia, menggali potensi manusia, serta untuk memandirikan masyarakat. Begitu pun target dan tujuan kegiatan pemberdayaan masyarakat yang dilakukan karang taruna Medal Jaya salah satu di antaranya adalah mampu menciptakan kesejahteraan bagi masyarakat melalui kegiatan sosial kemasyarakatan (bakti sosial, kesehatan keagamaan, dll), mampu menciptakan lapangan kerja dan usaha produktif dalam rangka pemberdayaan pemuda dalam kurun waktu lima tahun kedepan melalui kewirausahaan atau udah lain yang produktif dan mampu mengurangi angka pengangguran di Desa Cijemit sebesar $25 \%$ dalam kurun waktu lima tahun ke depan. 


\section{E. Kesimpulan}

Berdasarkan uraian di atas dapat disimpulkan bahwa Karang Taruna Medal Jaya di Desa CIjemit, Kecamatan Ciniru, Kabupaten Kuningan mempunyai beberapa program di antaranya bidang pendidikan dan kerohanian, bidang pelayanan kesejahteraan social, bidang rekreatif, olehraga dan kesenian, bidang pengembangan UEP dan UKM dan bidang pemberdayaan perempuan. Kegiatan tersebut merupakan kegiatan pemberdayaan masyarakat yang diikuti oleh masyarakat Desa Cijemit dengan kesadaran sendiri dan tanpa adanya paksaan. Kegiatan pemberdayaan masyarakat tersebut dilakukan karena adanya modal sosial dan nilai-nilai yang dimiliki oleh masyarakat di antaranya kebersamaan, kerjasama, tolong menolong, dan saling meng-hargai. Masing-masing bidang mempunyai kegiatan pemberdayaan sesuai tupoksinya, kegiatan di setiap bidang tersebut dilakukan bersamasama dengan masyarakat dengan target dan tujuan di antaranya mampu menciptakan kesejahteraan bagi masyarakat melalui kegiatan sosial kemasyarakatan (bakti sosial, kesehatan keagamaan, dll), mampu menciptakan lapangan kerja dan usaha produktif dalam rangka pemberdayaan pemuda dalam kurun waktu lima tahun kedepan melalui kewirausahaan atau udah lain yang produktif dan mampu mengurangi angka pengangguran di Desa Cijemit sebesar 25\% dalam kurun waktu lima tahun kedepan.

\section{DAFTAR PUSTAKA}

Azis Muslim. 2007. Konsep Dasar Pengembangan Masyarakat dalam Populis Jurnal Pengembangan Masyarakat. vol. 5:1.

Azis Muslim. tt. Paradigma Pengembangan Masyarakat dalam Suisyanto, Islam Dakwah dan Kesejahteraan Sosial. Yogyakarta: Jurusan PMI Fakultas Dakwah Uin Sunan Kalijaga Bekerjasama dengan IISEP-CIDA.

Ginanjar Kartasasmita. 1996. Pembangunan untuk Rakyat Memadukan Pertumbuhan dan Pe-merataan. Jakarta: Cides.

Juliansyah Noor. 2011. Metodologi Penelitian. Jakarta: Kencana Perdana Media group. 
Mulyadi Mohammad. 2018. Info Singkat, Vol. $X, \quad$ No. 09/I/Puslit.

Peraturan Menteri Sosial Republik Indonesia Nomor: 77/ HUK/ 208 tentang Pedoman Dasar Karang Taruna.

Sukriyanto. 2003. Pengembangan Masyarakat Islam Agama, Sosial, Ekonomi dan Budaya: Populis Jurnal

Pengembangan Masyarakat.

Edisi No. III / 2003.

Yogyakarta: UIN Sunan Kalijaga.

Zubaedi. 2013. Pengembangan Masyarakat Wacana dan Praktik. Jakarta: Kencana Prenada Media Group.

UN_Youth_Volunteers_Programme. pdfdalamhttps://www.unv.org /sites/default/files/UN_Youth _Volunteers_Programme.pdf
Booklet Relawan dalam www.p2kp.org/pustaka/.../rela wan/4_ISI_BOOKLET_Rela wan.doc.

Rancahan, Media Urun Rembug dan Berbagi Informasi http://rancahan.blogspot.co.id/ p/karang-taruna.html.

Cholisin, disampaikan pada Gladi Manajemen Pemerintahan Desa bagi Kepala Bagian/Kepala Urusan Hasil Pengisian Tahun 2011 di Lingkungan Kabupaten Sleman.

http://staff.uny.ac.id/sites/defa ult/files/tmp/PEMBERDAYA AN\%20MASYARAKAT.pdf Di akses pada Jum'at 14 Maret 2014.

Wawancara dengan Bapak AY. Bidang Pendidikan dan Kerohanian pada tanggal 21 Agustus 2017 
Wawancara dengan TH. Majlis

Permusyawaratan Karang

Taruna (MPKT) sekaligus

pengurus Rumah Belajar

Anak Bintang (RaJAB) pada

tanggal 15 Juli 2017.

Wawancara dengan AN. Bidang

Pelayanan Kesejahteraan

Sosial Karang Taruna Medal

Jaya pada tanggal 19 Juli 2017.

Observasi rumah WN pada tanggal 21 Agustus 2017.

Wawancara dengan DN Bidang ROK Karang Taruna Medal Jaya, pada tanggal 20 Agustus 2017.
Wawancara dengan WN. Bidang Pengembangan UEP dan UKM Karang Taruna Medal Jaya pada tanggal 21 Agustus 2017.

Wawancara dengan JN. Bidang Pemberdayaan Perempuan Karang Taruna Medal Jaya pada tanggal 21 Agustus 2017.

Profil Karang Taruna Medal Jaya Desa Cijemit Kecamatan Ciniru Kabupaten Kuningan Provinsi Jawa Barat. Bersama Membangun Masyarakat. Dokumen, 19 Juli 2017. 